\title{
Defective alloantigen-presenting capacity of 'Langerhans cell histiocytosis cells'
}

\author{
Raymond C H Yu, Jenny F Morris, Jon Pritchard, Tony C Chu
}

\begin{abstract}
The functional activity of skin cells derived from an infant who died of multisystem Langerhans cell histiocytosis (LCH) was examined. Involved and non-involved skin was obtained at postmortem examination within three hours of death; normal epidermal Langerhans cells and ' $\mathbf{L C H}$ cells' were separated by means of dispase digestion. The functional activity of different populations of CD1a positive cells was assessed using the conventional six day allogeneic mixed cell reaction. Compared with Langerhans cells from a healthy control, LCH cells showed minimal functional activity. However, Langerhans cells from non-involved skin showed normal and Langerhans cells overlying involved skin showed augmented functional activity. These findings suggest that $\mathrm{LCH}$ is a disease in which abnormal Langerhans cells accumulate and/or proliferate in various tissues but it does not affect the entire Langerhans cell population.
\end{abstract}

\section{(Arch Dis Child 1992;67:1370-2)}

Langerhans cell histiocytosis (LCH), a rare disorder of unknown cause affecting both children and adults, can involve many different organs and present to a wide range of medical specialties. LCH is now regarded as a 'reactive' disorder in which cells bearing the Langerhans cell phenotype accumulate and/or proliferate in physiologically normal and abnormal sites. ${ }^{12}$ The subsequent local tissue damage may cause organ dysfunction and in severe cases, -death. The tissue destruction in LCH is believed to be at least partly the result of excess cytokine production. ${ }^{3}$ Although lesional 'LCH cells' express most of the phenotypic markers as epidermal Langerhans cells ${ }^{4}$ including HLADR and the CDla complex, it is not known whether these cells carry the functional capacity of Langerhans cells. Functional studies have been severely hampered by the scarcity of fresh pathological specimens.

\section{Case report}

An 8 month old boy presented with a skin rash, discharging right ear, and easy bruising from the age of 3 months. Moderate hepatosplenomegaly was evident. Investigations showed anaemia (haemoglobin concentration $65 \mathrm{~g} / \mathrm{l}$ ) and thrombocytopenia (platelet count $3.0 \times 10^{9} / 1$ ). A skin biopsy specimen and bone marrow aspirate both demonstrated patchy infiltration by large cells with cleaved nuclei which showed positive immunostainings to $S 100$ and peanut agglutinin. A diagnosis of multisystem LCH was made according to the criteria of the Histiocyte Society. ${ }^{5}$

The child's illness progressed over the next nine months with pancytopenia requiring frequent transfusions and worsening hepatosplenomegaly. Several systemic agents including high dose systemic prednisolone, etoposide, vinblastine, and cyclosporin were tried with only transient benefit. From October 1990 he developed persistent unexplained abdominal pain, distension, and diarrhoea and in February 1991 he died of progressive disease. Postmortem examination carried out within three hours of death showed involvement of the bone marrow, lungs, skin, gastrointestinal tract, pancreas, liver, and spleen by LCH.

In order to assess the functional activity of LCH cells, samples of clinically normal skin and skin affected by LCH were taken. Small samples were snap frozen for immunohistochemistry using anti-CD1a monoclonal antibodies (MAbs) to identify the presence and localisation of Langerhans cells and LCH cells. Skin obtained from an adult patient who underwent abdominoplasty provided control epidermal Langerhans cells.

\section{ASSESSMENT OF LCH AND LANGERHANS CELL}

\section{FUNCTION}

An allogeneic mixed cell reaction was used to assess the functional activity of Langerhans cells and LCH cells. Ninety six well, round bottomed microtitre plates were used in a conventional six day assay. 'Stimulator cells' were prepared from both patient and control skin. The epidermis was separated using dispase $(2 \mathrm{mg} / \mathrm{ml})$ and a single cell suspension prepared by trypsinisation (trypsin $0.05 \%$ and EDTA $0.02 \%$ ). Dermal cells were isolated by collagenase digestion $(0.5$ $\mathrm{mg} / \mathrm{ml}$ ). Cells were resuspended in Roswell Park Memorial Institute medium containing $10 \%$ heat inactivated normal human serum with epidermal cells at $3 \times 10^{6} \mathrm{ml}$ and dermal cells at $10^{6} \mathrm{ml}$ and irradiated with $3000 \mathrm{cGy}$. Aliquots of $100 \mu \mathrm{l}$ of doubling dilutions of these cells were used per well in the functional assay. The four different stimulator cell populations were analysed using MAbs against CDla and HLA$D R$ with a standard indirect immunofluorescence technique.

Peripheral blood mononuclear cells (PBMC) separated from venous blood from three healthy volunteers were used as the 'responder cells' at $3 \times 10^{5}$ well. 
Results

PHENOTYPIC ANALYSIS

Non-involved skin showed a dense dermal infiltrate with rounded, CDla-positive $\mathrm{LCH}$ cells but with no epidermal invasion. Epidermal

Stimulator cells bearing CDIa and HLA-DR antigens as demonstrated by indirect immunofluorescence technique

\begin{tabular}{lccl}
\hline & CDIa & HLA-DR & Viability \\
\hline $\begin{array}{l}\text { Patient's normal epidermal } \\
\text { cells (\%) }\end{array}$ & 1 & 1 & 90 \\
$\begin{array}{l}\text { Patient's lesional epidermal } \\
\text { cells (\%) }\end{array}$ & 1 & 1 & 90 \\
$\begin{array}{c}\text { Patient's lesional dermal } \\
\text { cells (\%) }\end{array}$ & 40 & 41 & 90 \\
$\begin{array}{c}\text { Normal control epidermal } \\
\text { cells (\%) }\end{array}$ & 1 & 1 & 85 \\
\hline
\end{tabular}

\begin{tabular}{|l|}
\hline Normal epidermal cells \\
$\circ$ Lesional epidermal cells \\
$\square$ Lesional dermal cells \\
$\square$ Control epidermal cells
\end{tabular}
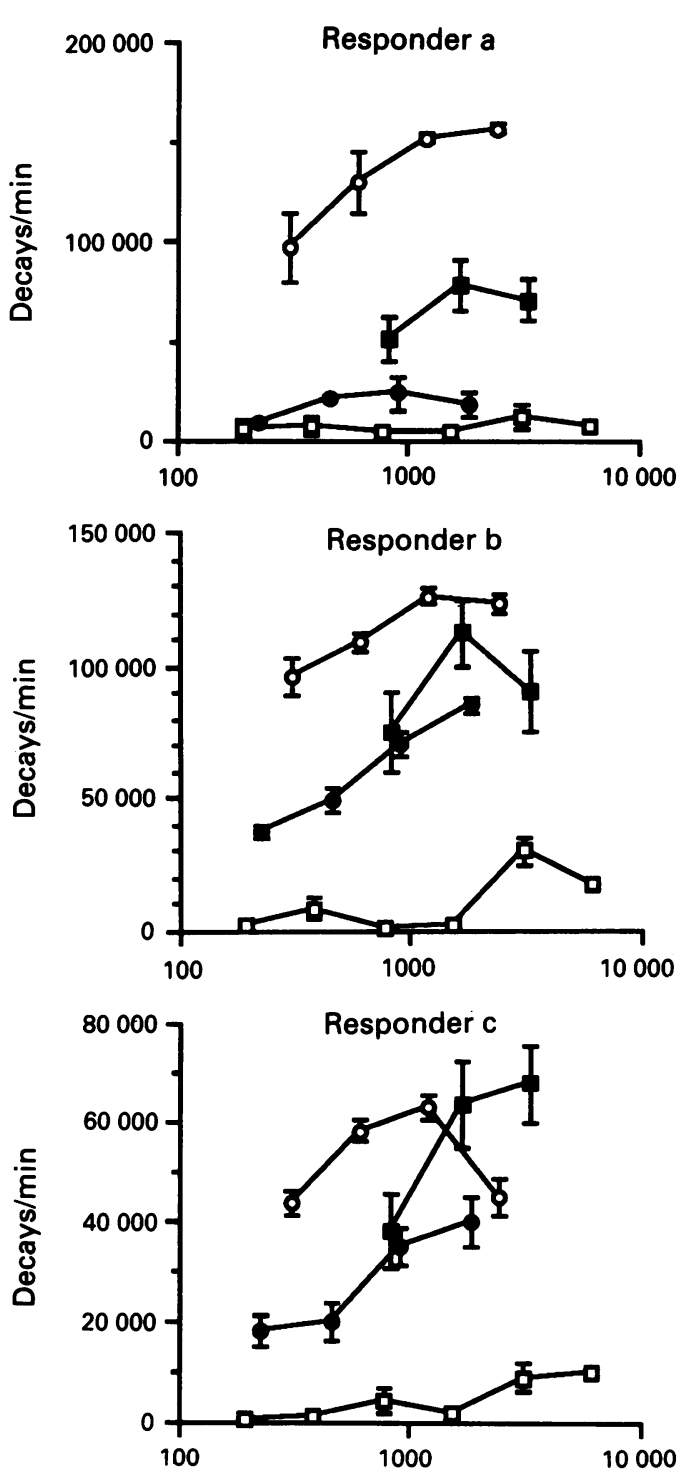

CD1a positive cells / well (log scale)

Alloantigen-presenting activity of various stimulator cell populations: patient's normal epidermal cells, patient's lesional epidermal cells, patient's lesional dermal cells, and normal control adult epidermal cells, to three responder populations $(a, b$, and $c)$ in a six day mixed cell reaction. The results are expressed as the mean $(S E M)$ of $\left[{ }^{3} H\right]$-thymidine incorporation in decays/min which have been corrected for baseline radioactivity in the negative controls.
Langerhans cells, which could be differentiated from LCH cells microscopically by their dendritic nature, were identified in epidermis at normal densities. Analysis of the stimulator cell populations is shown in the table.

\section{FUNCTIONAL ACTIVITY OF CELL POPULATIONS (FIGURE)}

CDla positive cells in lesional dermis demonstrated minimal functional activity on a per cell basis to the PBMC of all three responders. Langerhans cells from the non-involved epidermis showed similar dose related functional activity to Langerhans cells from the control skin. Langerhans cells from the epidermis overlying the involved dermis demonstrated an exaggerated functional activity against all three responder cell populations.

\section{Discussion}

Langerhans cells represent a well defined bone marrow derived cell population in the human epidermis. They constitutively express CDla and HLA-DR ${ }^{7}$ and have a vital role as antigen-presenting cells in the skin. ${ }^{8} \mathrm{LCH}$ is a reactive disorder in which cells bearing the Langerhans cell phenotype accumulate and/or proliferate in physiologically normal and abnormal sites. The subsequent local tissue damage may cause organ dysfunction and in severe cases, death. The in vitro functional capacity of $\mathrm{LCH}$ cells as antigen presenting cells has not so far been examined.

In the present study we use the allogeneic mixed cell reaction to assess the functional activity of LCH cells; this assay has been used extensively as an investigative tool for dissecting the functional activities of antigen-presenting cells. Antigen-presenting cells are believed to provide unique stimulatory signals to resting $T$ cells in primary allogeneic mixed cell response. ${ }^{9-11}$ In vitro allogeneic mixed cell reaction is believed to represent the sensitisation and effector phases of graft rejection in vivo. ${ }^{12}$

In this study we have demonstrated for the first time that, compared with normal Langerhans cells, lesional LCH cells from a patient with multisystem $\mathrm{LCH}$ are unable to present alloantigens to naive $\mathrm{T}$ cells in vitro. Although LCH cells share the same phenotype as Langerhans cells, they show defective functional activity. This discrepancy was not due to the different ways in which the epidermal and dermal cells were treated as we found that collagenase treatment does not significantly affect the function of normal Langerhans cells (unpublished data).

The Langerhans cells in normal skin from our patient showed normal functional activity. This finding suggests that the defective functional characteristic of $\mathrm{LCH}$ cells is localised to these cells and does not involve the entire Langerhans cell population. The significance of the increased functional activity of Langerhans cells overlying the involved dermal infiltrate is unclear but it is possible that cytokines generated in the underlying dermal infiltrate activate the overlying Langerhans cells. 
The profound restrictions on work in this disease due to the difficulties in obtaining fresh viable tissues make this study unique. Further studies will concentrate on purifying $\mathbf{L C H}$ cells in order that the present results can be validated. The results of this study do, however, strongly suggest that $\mathrm{LCH}$ is a disease in which functionally abnormal Langerhans cells accumulate and/or proliferate in various tissues but the abnormality seems to be confined to the lesional LCH cells.

This work was supported by a grant from the Marcus Nunn Histiocytosis X Research Fund. Dr J Pritchard receives financial support from the Imperial Cancer Research Fund.

1 McLelland J, Pritchard J, Chu AC. Current controversies. In: Osband ME, Pochedly C, eds. Histiocytosis $X$ (Hematology/Oncology Clinics of North America.) Philadelphia: W B Saunders, 1987:147-62.

2 McLelland J, Newton JA, Malone M, et al. Flow cytometric study of Langerhans cell histiocytes. Br f Dermatol 1989; study of Lange

3 Arenzana-Seidedos F, Barbey S, Virelizier JL, Kornprobst M,
Nezelof C. Histiocytosis X: purified (T6+) cells trom bone granuloma produce interleukin-1 and prostaglandin E2 in culture. F Clin Invest 1986;77:326-9.

4 Groh V, Gadner H, Radaszkiewicz T, et al. The phenotypic spectrum of histiocytosis X cells. F Invest Dermatol 1988; 90:441-7.

5 Chu T, D'Angio GJ, Favara BE, Ladisch S, Nesbit $M$ Pritchard J. Histiocytosis syndromes in children. Lancet 1987;ii:41-2.

6 Rowden G, Lewis MG, Sullivan AK. Ia antigen expression on human epidermal Langerhans cells. Nature 1977;268: human

7 Murphy GF, Bhan AK, Sato SM, Mihm MC Jr, Harrist TJ. A new immunologic marker for human Langerhans cells. $N$ Engl f Med 1981;304:791-2.

8 Bjercke S, Elgo J, Braathen L, Thorsby E. Enriched epidermal Langerhans cell are potent antigen-presenting cells for T cells. F Invest Dermatol 1984;83:286-9.

9 Inaba K, Steinman RM. Resting and sensitized T lymphocyte exhibit distinct stimulatory (antigen-presenting cell) requirements for growth and lymphokine release. $\mathcal{f} E x p$ Med 1984;160:1717-35.

10 Inaba K, Schuler G, Witmer MD, Valinsky J, Atassi B Steinman RM. Immunologic properties of purified epidermal Langerhans cells distinct requirements for stimulation of unprimed and sensitized T lymphocytes. $\mathcal{F}$ ExpMed 1986;164:605-13.

11 Austyn JM. Lymphoid dendritic cells. Immunology 1987;62: $161-70$

12 Morris PJ. The immunology of rejection. In: Morris PJ, ed. Kidney transplantation, principles and practice. New York: Grune and Stratton. 1984:15-36. 